\title{
Mammographic density and estrogen receptor $\alpha$ gene polymorphism in Javanese women
}

\author{
Lina Choridah ${ }^{1 *}$, Teguh Aryandono ${ }^{2}$, Arif Faisal ${ }^{1}$, Ahmad Hamim Sadewa ${ }^{3}$, Dewajani \\ Purnomosari ${ }^{4}$ \\ 'Department of Radiology, ${ }^{2}$ Department of Surgery, ${ }^{3}$ Department of Biochemistry, \\ ${ }^{4}$ Department of Histology/Molecular Biology, Faculty of Medicine, Universitas Gadjah \\ Mada, Yogyakarta, Indonesia
}

\begin{abstract}
Estrogen plays important roles in breast cancer as it binds its receptor in breast tissue. The most studied variants in estrogen receptor $\alpha$ encoded by ESR 1 gene are the ESR 1 $P v u l l$ and $X b a l$ polymorphisms, which were associated with lower sensitivity to estrogen. We determined the proportion of ESR1 Xbal and Pvull polymorphisms in Javanese woman in Yogyakarta, Indonesia and analyzed the correlation between genetic variations with mammogram density. ESR $1 \mathrm{Xbal}$ and Pvull polymorphisms of 50 cases and 58 controls were identified using PCR-RFLP. Breast density was assessed based on digitizer mammograms. Quantitative analysis was performed using an interactive program based on cumulus of two thresholds. Mean of density and frequencies of SNPs were compared between cases and controls to identify the association between SNPs and cancer susceptibility. Mammographic density was significantly higher in cases $(52 \%)$ than controls $(0.41 \%)$ ( $p$ $<0.05)$. Women with one or two copies of the Pvull T allele and Xbal A allele had higher mammographic density compared with women with $C$ and $G$ alleles, respectively. The proportion between PP and TT genotype was not statistically significant $(p>0.05)$, while the proportion between AA and GG was significantly different $(p<0.05)$. Haplotype 2 (CG/PX) was associated with lower sensitivity to estrogen and reflects a decrease of mammographic density. These findings were consistent with other studies that showed that ESR1 polymorphisms may affect breast cancer risk through differences in breast density.
\end{abstract}

\section{ABSTRAK}

Estrogen memainkan peran penting dalam kanker payudara karena mengikat reseptor di jaringan payudara. Varian yang paling banyak dipelajari di reseptor estrogen $\alpha$ yang dikode oleh gen ESR1 adalah polimorfisme ESR1 Pvull dan Xbal, yang terkait dengan sensitivitas yang lebih rendah untuk estrogen. Kami menentukan proporsi polimorfisme ESR1 Xbal dan Pvull pada wanita Jawa di Yogyakarta, Indonesia dan menganalisis korelasi antara variasi genetik dengan kepadatan mammogram. Polimorfisme ESR1 Xbal dan Pvull dari 50 kasus dan 58 kontrol diidentifikasi menggunakan PCR-RFLP. Kepadatan payudara dinilai berdasarkan digitizer mammogram. Analisis kuantitatif dilakukan dengan menggunakan program interaktif berbasis cumulus dari dua ambang batas. Rata-rata kepadatan dan frekuensi SNP dibandingkan antara kasus dan kontrol untuk mengidentifikasi hubungan antara SNP dan kerentanan terhadap kanker. Kepadatan mammografi secara signifikan lebih tinggi pada kasus $(52 \%)$ dibandingkan kontrol $(0,41 \%)(p<0,05)$. Wanita dengan satu atau dua salinan alel Pvull T dan Xbal A memiliki kepadatan mammografi lebih tinggi

Corresponding author: linachoridah@ugm.ac.id 
dibandingkan dengan wanita dengan alel C dan G, secara berurutan. Proporsi antara genotipe PP dan TT tidak signifikan secara statistik $(p>0,05)$, sedangkan proporsi antara AA dan GG berbeda secara signifikan ( $p<0,05)$. Haplotype 2 (CG / PX) berkaitan dengan sensitivitas yang lebih rendah terhadap estrogen dan mencerminkan penurunan kepadatan mamografi. Temuan ini konsisten dengan penelitian lain yang menunjukkan bahwa polimorfisme ESR1 dapat mempengaruhi risiko kanker payudara melalui perbedaan kepadatan payudara.

Keywords: breast cancer - DNA polymorphism - ESR1 Pvull - ESR1 Xbal - mammogram Digitizer

\section{INTRODUCTION}

Breast cancer $(\mathrm{BC})$ is the highest ranked malignancy in women in the world and is particularly frequent in Yogyakarta, Java, Indonesia. ${ }^{1,2}$ Estrogen plays an important role in the occurrence of $\mathrm{BC}$ through inducing proliferation and genotoxic effects by mechanisms involving estrogen binding to its receptor in breast tissue. However, the detailed mechanism of the induction of $\mathrm{BC}$ carcinogenesis is not fully understood. ${ }^{3}$ There are two types of estrogen receptor, estrogen receptor alpha, which is the main estrogen receptor that is encoded by the ESRI gene, and estrogen receptor beta which is encoded by ESR2 gene. $^{4}$ ESR 1 is one of the most important mediators of hormonal response in estrogen-sensitive tissues such as the breast and plays a crucial role in breast growth and differentiation as well as in the development of $_{\text {cancer. }}^{5}$

Mammography density reflects the number of stromal and epithelial cells and is one of the strongest risk factors for BC. Some studies showed that women with a high density mammography pattern have a risk of BC 4-6 times higher than those with a low density pattern. ${ }^{6}$ An annual mammography examination is currently recommended for women over the age of 40 years, ${ }^{1}$ but not for women younger than 40 years, due to pain from compression techniques during the examination and the risk of radiation hazard. ${ }^{7}$
Many studies have demonstrated evidence for the influence of estrogen on mammographic density. ${ }^{8-10}$ Women with hormone replacement therapy showed increased breast density. ${ }^{8,9}$ Conversely, tamoxifen, a selective ER modulator and anti-estrogen, has been shown to decrease breast density and cancer risk. ${ }^{10}$ This suggests that the association of mammographic density with $\mathrm{BC}$ risk may occur through an estrogenic mechanism.

Research on the relationship between ESR 1 polymorphism and mammographic density revealed different frequencies of ESR 1 polymorphisms in different ethnics. ${ }^{11,12}$ The most studied variants in the ESRl gene are the $P v u \mathrm{II}$ and $X b a \mathrm{I}$ polymorphisms, which have been associated with lower sensitivity to estrogen. ${ }^{13}$ Determining the proportions of ESR $1 \mathrm{Xba \textrm {I }}$ and PvuII polymorphisms in BC cases in Yogyakarta may provide information that can be used as a preventive measure, especially for younger women who cannot be examined with mammography and as a reference for some interventions to reduce $\mathrm{BC}$ risk.

\section{MATERIALS AND METHODS}

\section{Subjects}

This study included BC patients admitted to Dr. Sardjito Genera Hospital, Yogyakarta in 2009-2010 who underwent pre-surgery mammography examinations, had been 
diagnosed with $\mathrm{BC}$ and undergone mastectomy. The controls included women with no benign lesion based on breast examination, either using ultrasonography or mammography. All subjects agreed to participate in the study and provided signed informed consent. One hundred and eight blood samples from cases $(n=50)$ and controls $(n=58)$ were transported to the Molecular Biology Laboratory Faculty of Medicine Universitas Gadjah Mada for DNA extraction. Clinical data were obtained from medical records and directly filling out the questionnaire.

\section{Density analysis}

Density analysis was carried out after the first mammogram scanning steps. The shape of a negative mammogram film is converted into digital form using a mammogram digitizer. Density analysis was performed using a special program. Quantitative analysis was performed using base system computerassisted methods of measurement with an interactive program based on two thresholds. The first threshold distinguishes breast tissue from the background in the mammogram. The second threshold is used to distinguish tissue in the breast itself.

\section{Polymerase chain reaction-restriction fragment length polymorphism (PCR- RFLP)}

Genomic DNA was extracted with saturated $\mathrm{NaCl}$ method. PCR was conducted in a total reaction volume of $25 \mu \mathrm{L}$, consisting of $100 \mathrm{ng}$ genomic DNA, $2.5 \mu \mathrm{L} 10 \mathrm{X}$ PCR buffer, $0.75 \mu \mathrm{L} \mathrm{MgCl} 50 \mathrm{~mm}, 0.2 \mu \mathrm{L} 25-\mathrm{mm}$ dNTPs, $0.1 \mu \mathrm{L}$ Platinum Taq (Invitrogen) and 10 pmol of each primer $1 \mu \mathrm{L}$ forwardand reverse-coupled with DHPLC. The PCR reaction conditions were as follows: $95^{\circ} \mathrm{C}$ 5 min, followed by 35 cycles of $95^{\circ} \mathrm{C} 35 \mathrm{~s}$, annealing temperatures of $15 \mathrm{~s}$ and $72^{\circ} \mathrm{C}$ for $25 \mathrm{~s}$, followed by a final extension at $72^{\circ} \mathrm{C}$ for 10 min. PCR products were digested with $X b a \mathrm{I}$ and $P v u \mathrm{II}$ restriction enzymes (New England Biolabs) and visualized on 2.5-3\% agarose gels containing ethidium bromide.

The homozygous mutant in ESR1 XbaI AA shows two bands sized 936 and 436 bp, the heterozygous AG produces three bands (1327, 936 and $436 \mathrm{bp}$ ), and the homozygous wildtype GG shows a single band size of 1327 bp. ${ }^{9}$ For ESR1 PvuII, the TT homozygous mutant shows two bands sized 982 and 390 $\mathrm{bp}$, the heterozygous CT produces three bands (1372, 982 and $390 \mathrm{bp}$ ), and the homozygous CC wildtype shows a single band of $1327 \mathrm{bp} .{ }^{14}$

\section{Statistical analysis}

Data were analyzed with student t-test statistical analyses. $P$-values less than 0.05 were considered significant.

\section{RESULTS}

This study included 108 BC research subjects in Dr. Sardjito General Hospital, Yogyakarta between 2009 and 2010. The average age of subjects was 50.6 years and average age of controls was 48.72 years. The youngest subject among them was 33 years old and the oldest was 68 years old. There was no significant difference of age between cases and controls $(p>0.05)$. The percent mammogram density of cases was $52 \%$ and controls was $41 \% \%$. Compare means with independent sample t-test between cases and controls was significantly different $(p<0.05)$. We next performed PCR-RFLP of all cases. The ESR1 PvuII TT homozygous mutant showes two bands of 982 and $390 \mathrm{bp}$, the heterozygous CT produces three bands of 1372, 982 and $390 \mathrm{bp}$, and the homozygous CC wildtype showes one band of $1327 \mathrm{bp}$ (FIGURE 1). ${ }^{14}$ Furthermore the frequency of ESR1 PvuII polymorphism is presented in TABLE 1. 


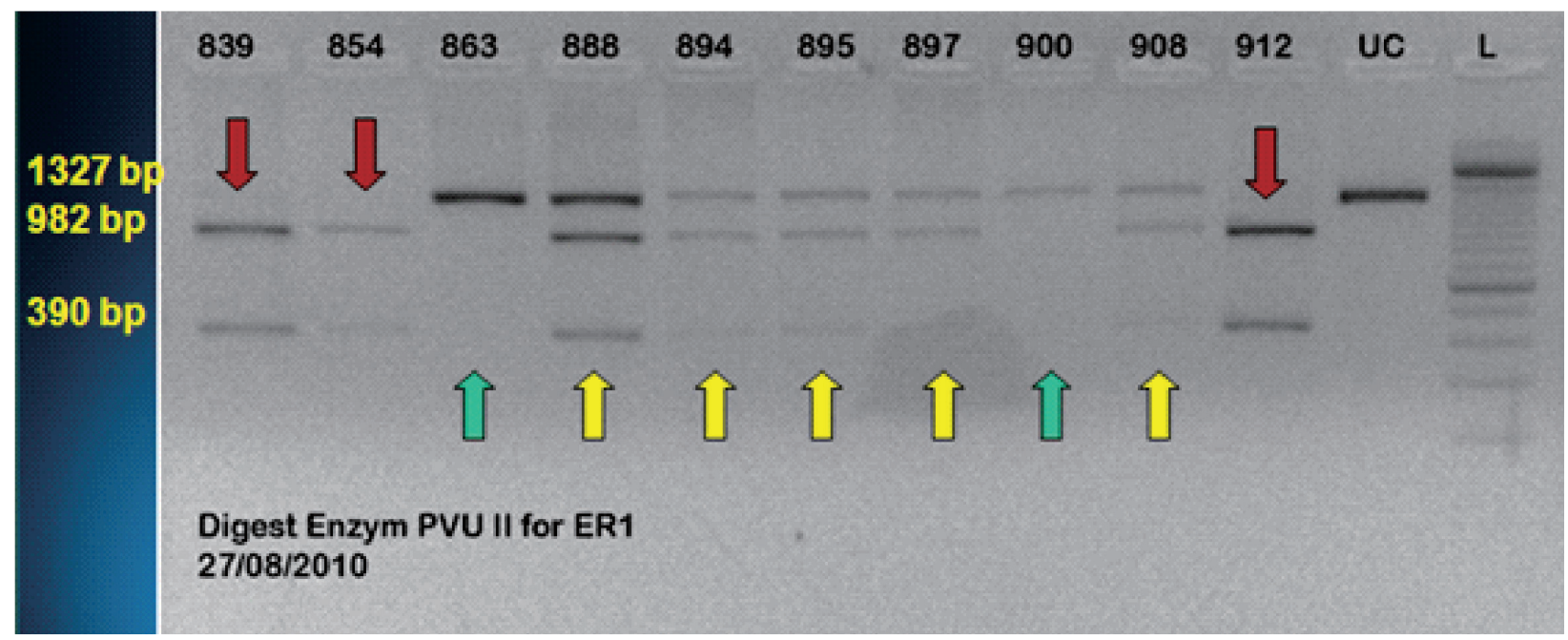

Green arrow: $\mathrm{C} / \mathrm{C}$, yellow arrow: $\mathrm{C} / \mathrm{T}$, red arrow: $\mathrm{T} / \mathrm{T}$

FIGURE 1. ESR1 PvuII polymorphism

TABLE 1. Frequency of ESR1 PvuII polymorphism

\begin{tabular}{ccccc}
\hline \multirow{2}{*}{ Allele } & \multicolumn{2}{c}{ Case } & \multicolumn{2}{c}{ Control } \\
\cline { 2 - 5 } & Frequency & $\%$ & Frequency & $\%$ \\
\hline TT & 15 & 30 & 6 & 10.3 \\
TC & 28 & 56 & 33 & 56.9 \\
CC & 7 & 14 & 19 & 32.8 \\
\hline
\end{tabular}

The homozygous mutant in the ESR1 $X b a$ I AA shows two bands sized 936 and 436 $\mathrm{bp}$, the heterozygous AG produces three bands (1327, 936 and $436 \mathrm{bp}$ ), and the homozygous wildtype GG shows a band size of 1327 bp (FIGURE 2). ${ }^{14}$ Furthermore the frequency of ESR $1 \mathrm{Xba \textrm {I }}$ polymorphism is presented in TABLE 2.

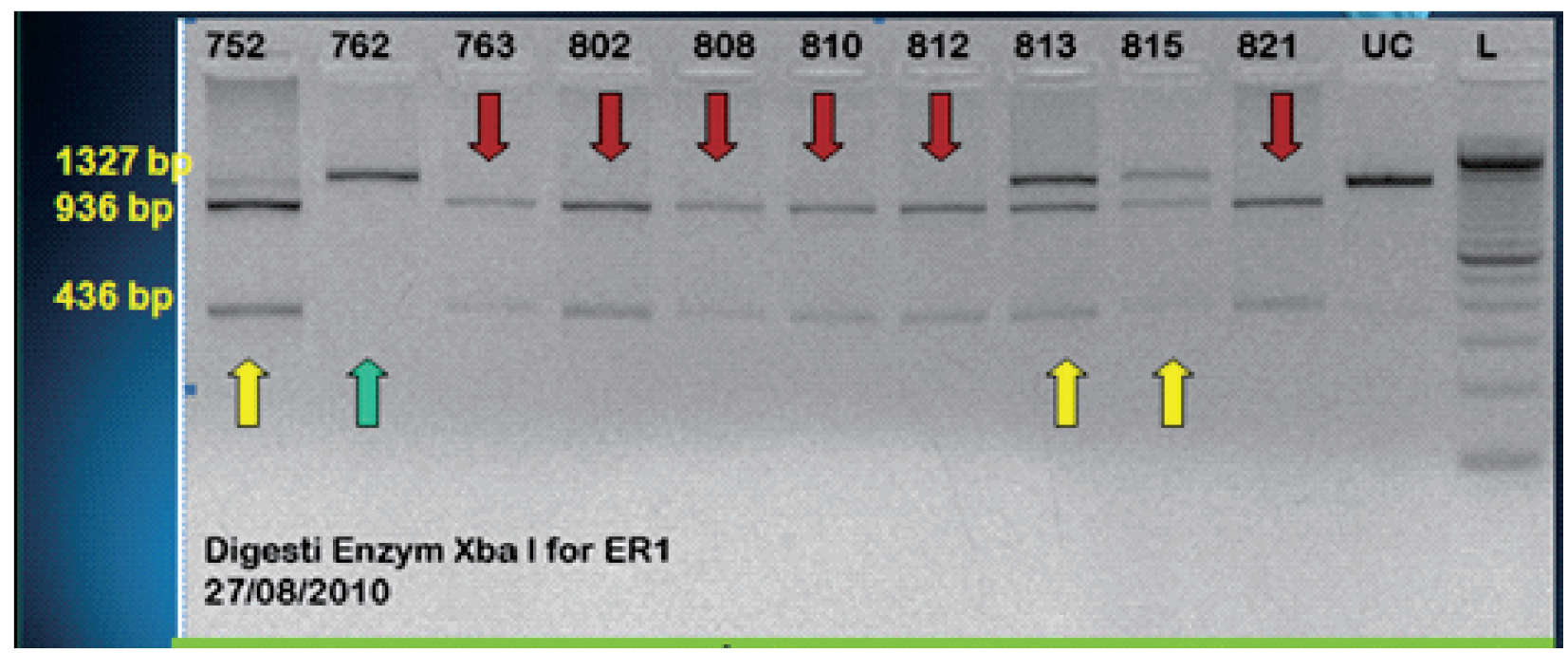

Green arrow: G/G, yellow arrow: G/A, red arrow: A/A

FIGURE 2. Polymorphism ESR1 XbaI 
TABLE 2. Frequency of ESR1 XbaI polymorphism

\begin{tabular}{ccccc}
\hline \multirow{2}{*}{ Allele } & \multicolumn{2}{c}{ Case } & \multicolumn{2}{c}{ Control } \\
\cline { 2 - 5 } & Frequency & $\%$ & Frequency & $\%$ \\
\hline GG & 2 & 4 & 10 & 17.2 \\
AG & 20 & 40 & 25 & 43.1 \\
AA & 28 & 56 & 23 & 39.7 \\
\hline
\end{tabular}

We also analyzed and compared the mammography density in all groups. The mean percentage density in women with one or two copies of the PvuII p allele (CT/Pp and TT/pp, $49 \%$ and $48 \%$, respectively) was higher than in those with the CC/PP genotype $(39 \%)$. However, this difference did not show statistical significance (TT vs. CC, $\mathrm{p}>$ $0.05)$. Women with one or two copies of the $X b a I \times$ allele had a higher mean percentage density (AG/Xx and $\mathrm{AA} / \mathrm{xx}, 49 \%$ and $47 \%$, respectively) than those with the $\mathrm{GG} / \mathrm{XX}$ genotype (32\%), and we detected a significant difference between AA and GG genotypes $(\mathrm{p}<0.05)$. The percentages of heterozygous (CT) and homozygous (TT) PvuII in BC cases were higher $(86 \%)$ than those in control (66\%). The percentages of heterozygous (AG) and homozygous (AA) $\mathrm{XbaI}$ were also higher in $\mathrm{BC}$ cases $(96 \%)$ compared with controls $(82 \%)$.

\section{DISCUSSION}

The average age of the subjects in this study was 50.6 years. Age less than 50 years as many as $25(50 \%)$, equal to or more than 50 years 25 subjects $(50 \%)$. A study in the United Kingdom in 2007 reported that most GC patients are over 50 years of age $(81 \%){ }^{15}$ These data reflect the high number of young GC survivors in Indonesia, especially in Java, which is consistent with the pattern of GC in Asian females. ${ }^{16}$ In general, the frequency of cancer incidence will increase in line with age.
This increased incidence can be explained by the accumulation of somatic mutations in the human body. Another factor that plays a role is the decline in immune competence that accompanies the aging process. Although very few cases of $\mathrm{BC}$ occur in women in their teens or early $20 \mathrm{~s}, \mathrm{BC}$ is the second most common cancer diagnosed in women under 35 years. Approximately 1,400 BC cases are diagnosed each year among women aged 35-39 years. $\mathrm{BC}$ incidence rates generally increase with age, with the largest rate of increase before menopause. ${ }^{1}$ The differences in rates between patients after BC in Indonesia and in developed countries is probably because of the lower life expectancy in Indonesia and may also be due to specific genetic factors.

\section{Mammogram density}

High breast density on mammography is one of the strongest risk factors for $\mathrm{BC}$. Breast density seen on a mammogram reflects differences in the number of stromal and epithelial cells and fatty tissue in the breast. Stroma and epithelium are radiologically will provide the density, while fat provides a radioluscent. ${ }^{17}$ The average mammographic density of $\mathrm{BC}$ cases is $52 \%$ with an average age $50.6 \%$, but in control group $41 \%$ with an average age $48.7 \%(\mathrm{p}<0.05)$. A previous study reported an average mammographic density in normal pre-menopausal women with an average age of 44.75 years of $28.7 \%$ and $23.64 \%$ in post-menopausal with an 
average age of 55.95 years. ${ }^{18}$ Another study reported an average density in $\mathrm{BC}$ patients with an average age of 57.4 years of $36.7 \%$, while the control group showed $30.6 \%$ with an average age of 56.8 years. ${ }^{19}$ These data showed that our study subjects had a higher average mammogram density than previous studies. Martin and Boyd proposed a hypothesis that the biological occurrence of mammogram density is determined by cell proliferation (mitogenesis) and cell damage caused by mutagens (mutagenesis). Both mitogenesis and mutagenesis are affected by many factors, including age, reproductive status, endogenous hormones and growth factors. $^{20}$ The high-density mammogram data in this study support the hypothesis that mammogram density is one of the risks for $\mathrm{BC}$.

\section{DNA polymorphisms $X b a I$ and $P v u I I$ in ESR1}

Estrogen is a mitogen that affects physiological processes including cell growth. Estrogen is found in breast tissue and affects the regulation of cell growth. High estrogen levels are also reportedly associated with an increased risk of BC. Estrogen mostly exerts its cellular action through binding its receptor. Between the two forms of estrogen receptor $\alpha$ and $b$, estrogen receptor $\alpha$ plays an important role in $\mathrm{BC}$ because of its high prevalence in breast tissue. ${ }^{21}$ The ESR1 gene, also known as $E S R \alpha$, is located on human chromosome 6q25. ESR1 is a core receptor that mediates the action of estrogen or other steroid hormones that regulate gene transcription, especially in estrogen-sensitive tissues such as breast, and plays a crucial role in the growth and differentiation of BC. Most research has focused on the ESR I PvuII $(\mathrm{C} / \mathrm{T})$ and $\mathrm{XbaI}(\mathrm{G} / \mathrm{A})$ polymorphisms in intron $1 .{ }^{21}$ Both variants have implications in affecting transcription and gene expression. Some studies also indicate an increased risk of $\mathrm{BC}$ with polymorphisms at allele $\mathrm{A}$ and $\mathrm{T}$ (homozygous mutant) of $X b a \mathrm{I}$ and $P v u \mathrm{II} .{ }^{22}$

In this study, percentage of heterozygous (CT) and homozygous mutant (TT) of PvuII in breast cancer cases $(86 \%)$ ) higher than controls $(66 \%)$. The percentage of heterozygous (AG) and homozygous mutant (AA) of $\mathrm{XbaI}$ in breast cancer cases $(96 \%)$ also higher than controls $(82 \%)$. The average percentage density was higher in women with one or two copies of the $P v u$ II $\mathrm{p}$ allele (CT/Pp and TT/pp, $49 \%$ and $48 \%$, respectively) than in those with the $\mathrm{CC} /$ PP genotype (39\%). However, this difference did not show statistical significance (TT vs. CC). Women with one or two copies of the $X b a \mathrm{I} \times$ allele had higher mean percentage density (AG/Xx and AA/xx, 49\% and 47\%, respectively) than those with the GG/XX genotype (32\%), and we detected a significant difference between AA and GG genotypes.

The results of our study are consistent with those published by van Duijnhoven. ${ }^{23}$ Mammographic density was significantly higher in women with one or two copies of p (T) allele in ESR1 PvuII. Haplotype ESR1 gene $1(\mathrm{px} / \mathrm{TA})$ was also associated with increased mammographic density while haplotype 2 (PX/CG) was associated with a decrease in density. On the whole subject is a breast cancer contained a high percentage and high mammographic density of heterozygous and homozygous mutant compared with homozygous wild type at ESR $1 \mathrm{Xba \textrm {I }}$ and ESR1 PvuII. The difference between the two groups which show high estrogen that effect mammographic density that is strong risk of breast cancer. Crandal et al. showed that genetic variation in sex steroids or estrogen receptors are in production in breast showed different degrees of proliferation that affect radiological picture as a mammogram density 
differences. ${ }^{22}$ The existence of sex steroid metabolic enzymes and ESRs in breast tissue caused an activation of local estrogen that could potentially lead to reactive metabolites in breast tissue and may have a role in the initiation and promotion of carcinogenesis.

\section{CONCLUSION}

Our study showed that haplotype 1 (px/ TA) of ESR1 gene is associated with high sensitivity to estrogen and reflects an increase of mammographic density. Haplotype 2 (CG/PX) is associated with lower sensitivity to estrogen and reflects a decrease of mammographic density. Our findings support the view that ESRI polymorphisms may affect $\mathrm{BC}$ risk through differences in breast density.

\section{ACKNOWLEDGEMENT}

We would like to thank all patients who have participated in this study.

\section{REFERENCES}

1. American Cancer Society. Can breast cancer be found early? American Cancer Society, 2010.

2. Ghozali A. Registrasi kanker. Proceedings of Seminar Onkologi Yayasan Kanker Indonesia. 2009.

3. Cuzick J. Epidemiology of breast cancerselected highlights. The Breast 2003; 12(6):405-11. http://dx.doi.org/10.1016/ S0960-9776(03)00144-9

4. Couse JF, Lindzey J, Grandien K, Gustafsson JA, Korach KS. Tissue distribution and quantitative analysis of estrogen receptor- $\alpha$ $(\mathrm{ER} \alpha)$ and estrogen receptor- $\beta$ (ER $\beta)$ messenger ribonucleic acid in the wild-type and ER $\alpha$-knockout mouse. Endocrinology 1997; 138(11):4613-21. http://dx.doi. org/10.1210/endo.138.11.5496
5. Gruber CJ, Tschugguel W, Schneeberger C, Huber JS. Production and actions of estrogens. N Engl J Med 2002; 346(5):340-52. http:// dx.doi.org/10.1056/ NEJMra000471

6. Boyd NF, Byng JW, Jong RA, Fishell EK, Little LE, Miller AB, et al. Quantitative classification of mammographic densities and breast cancer risk: results from the canadian national breast screening study. J Natl Cancer Inst 1995; 87(9):670-5. http://doi. org/10.1093/jnci/87.9.670

7. Hall F. Mammographic screening in younger women at high risk. Am J Roentgenol 2009; 193(4):1188. http://dx.doi.org/10.2214/ AJR.09.2753

8. Persson I, Thurfjell E, Holmberg L. Effect of estrogen and estrogen-progestin replacement regimens on mammographic breast parenchymal density. J Clin Oncol 1997; 15(10):3201-7. http://dx.doi.org/10.1200/ jco.1997.15.10.3201

9. Greendale GA, Reboussin BA, Slone S, Wasilauskas C, Pike MC, Ursin G. Postmenopausal hormone therapy and change in mammographic density. J Natl Cancer Inst 2003; 95(1):30-7. http://dx.doi.org/10.1093/ jnci/95.1.30

10. Cuzick J, Warwick J, Pinney E, Warren RM, Duffy SW. Tamoxifen and breast density in women at increased risk of breast cancer. $\mathrm{J}$ Natl Cancer Inst 2004; 96(8):621-28. http:// dx.doi.org/10.1093/jnci/djh106

11. Shimada N, Iwasaki M, Kasuga Y, Yokoyama $\mathrm{S}$, Onuma $\mathrm{H}$, Nishimura $\mathrm{H}$ et al. Genetic polymorphisms in estrogen metabolism and breast cancer risk in case-control studies in Japanese, Japanese Brazilians and nonJapanese Brazilians. J Hum Genet 2009; 54(4):209-15. http://dx.doi.org/10.1038/jhg.2009.13

12. Qiu L, Yao L, Mao C, Yu K, Zhan P, Chen B, et al. Lack of association of CYP1A2-164 $\mathrm{A} / \mathrm{C}$ polymorphism with breast cancer 
susceptibility: a meta-analysis involving 17,600 subjects. Breast Cancer Res Treat 2010; 122(2):521-5.

http://dx.doi.org/10.1007/s10549-009-0731-4

13. Ding $\mathrm{H}, \mathrm{Fu} \mathrm{Y}$, Chen W, Wang Z. COMT Val158Met polymorphism and breast cancer risk: evidence from 26 case-control studies. Breast Cancer Res Treat 2010; 123(1):26570. http://dx.doi.org/10.1007/s10549-0100759-5

14. BoroumandM, GhaediM, Mohammadtaghvaei N, Pourgholi L, Anvari MS, Davoodi G, et al. Lipid profile and inflammatory markers associated with estrogen receptor a PvuII and XbaI gene polymorphisms. Transl Res 2009; 153(6):288:95.

http://dx.doi.org/10.1016/j.trsl.2009.02.006

15. Cancer Research UK. Breast Cancer-UK. 2011.

from:http://www.cancerresearchuk.org/ cancer-info/cancerstats/types/breast/ incidence/uk-breast-cancer-incidencestatistics\#age

16. Leong SP, Shen ZZ, Liu TJ, Agarwal G, Tajima T, Paik NS, et al. Is breast cancer the same disease in Asian and Western countries? World J Surg 2010; 34(10):2308-24. http:// dx.doi.org/10.1007/s00268-010-0683-1

17. Yaffe MJ. Measurement of mammographic density. Breast Cancer Res 2008; 10(3):20918. http://dx.doi.org/10.1186/bcr2102

18. Boyd NF, Guo H, Martin LJ, Sun L, Stone J, Fishell E, et al. Mammographic density and the risk and detection of breast cancer. N Engl J Med 2007; 356(3):227-36. http://dx.doi.org/10.1056/NEJMoa062790
19. Takata Y, Mascarinec G, Le Marchand L. Breast density and polymorphisms in genes coding for CYPA2 and COMT: the Multiethnic Cohort. BMC Cancer 2007; 7:30. http://dx.doi.org/10.1186/1471-2407-7-30

20. Martin LJ, Boyd NF. Mammographic density, potential mechanisms of breast cancer risk associated with mammographic density: hypotheses based on epidemiological evidence. Breast Cancer Res 2008; 10(1):201. http://dx.doi.org/10.1186/bcr1831

21. Slattery ML, Sweeney C, Herrick J, Wolff R, Baumgartner K, Giuliano A, et al. ESR1, AR, body size, and breast cancer risk in Hispanic and non-Hispanic white women living in the Southwestern United States. Breast Cancer Res Treat 2007; 105(3):327-35. http://dx.doi.org/10.1007/s10549-006-9453-z

22. Crandal CJ, Sehl ME, Crawford SL, Gold EB, Habel LA, Butler LM, et al. Sex steroid metabolism polymorphisms and mammographic density in pre- and early perimenopausal women. Breast Cancer Res 2009; 11(4):R5. http://dx.doi.org/10.1186/bcr2340

23. van Duijnhoven FJ, Bezemer ID, Peeters PH, Roest M, Uitterlinden AG, Grobbee DE, et al. Polymophism in the estrogen receptor $\alpha$ gene and mammographic density. Cancer Epidemiol Biomarkers Prev 2005; 14(11 Pt 1):2655-60. http://dx.doi.org/10.1158/ 1055-9965.EPI05-0398 